\section{What It Means to Be 98\% Chimpanzee: Apes, People, and Their Genes}

\author{
by Jonathan Marks \\ University of California Press, \$27.50, \\ 320 pp, 2002
}

\section{ReVIEWED By RaNdolPh M. NesSE \\ Departments of Psychiatry and Psychology University of Michigan \\ Ann Arbor, Michigan, USA}

Such a catchy title suggests the reader will get a detailed and enthusiastic answer to the question it poses. But Jonathan Marks is not very interested in what it means to be $98 \%$ chimpanzee. Indeed, he is confident that the interest shown by others is all a mistake, one with severe political and moral consequences. His main thesis is that scientists, especially geneticists, are products of their cultures who unknowingly impose their values and categories, with dire effects. He hopes that the examples he offers will encourage scientists to become more humble, more culturally aware and perhaps more supportive of his political agendas. However, most scientists will see this book as an attack on their motives and science itself by someone who does not understand science the way they do, making it hard for them to even consider his thesis.

The chapters are adapted from previously published essays and book reviews. The essays are all critiques, and the reviews are all attacks. He has done a fine job of expanding and editing them so they fit together into a book format; however, the topics cover a vast territory. Molecular anthropology, behavioral genetics, genetic differences between groups, sociobiology and implications for animal rights are all in this stew, with few distinctions made between these disparate fields with their fundamentally different questions and methods. All are seen as manifestations of the same misguided scientific confidence in genetic/evolutionary studies that he thinks lacks respect for other ways of knowing. In the last chapter he extends this critique to all of science and even to rationality itself, but the other chapters focus on one or another aspect of how little genetics and evolution have to tell us about humans. This theme and the political tone are evident by page 3 , where he says, "What I will show in this book is that when the cutting-edge technology of molecular genetics has been wed to a 'folk knowledge' of anthropology, the results have invariably been of exceedingly limited value. This was true in the 1920s, when geneticists sought to rewrite our understanding of social issues by blaming poverty on the genes of the poor."

One of his central points is that scientists naively incorporate their cultural assumptions in the categories they use. He offers many telling examples, mostly historical and based on anthropological studies of race. At one point he goes so far as to say that there is no scientific basis for preferring some categories to others: "Sameness/otherness is a philosophical paradox that is resolved by argument, not fact." In this vein, he begins by arguing that humans are vastly different from other apes, irrespective of the degree of genetic difference. This could make the useful point that closely related species can have very different adaptations to different niches, but the emotional fervor of his prose makes it seem like a direct continuation of the anthropocentric fearfulness that has motivated opposition to scientific studies of humans since the Enlightenment, and especially since 1859 . He says as much on page 222: "That's the problem with Darwinian theory, of course. It tells us our ancestors were kin to apes, the products of eons of ordinary biological processes of survival and reproduction, and not merely zapped into

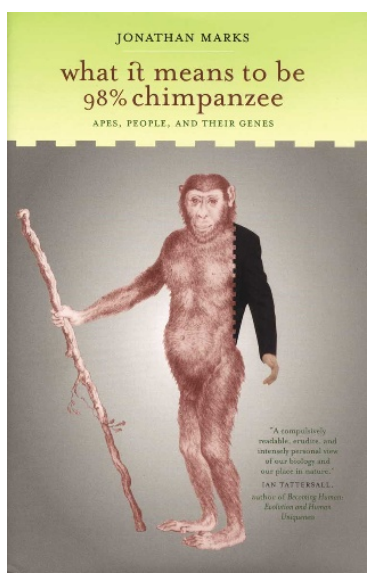
existence in the Garden of Eden, but it doesn't tell us what that means or what to do about it. It just walks away from the wreckage."

One can't help but sympathize with such distress, but why on earth does he think evolution should tell us "what to do about it"? Much of his moral passion seems to arise from the prevalent but serious misconception that scientific discoveries about the origins of human behavioral tendencies lead directly to moral precepts about what we ought to do. On page 142 he offers one of the more vivid examples ever published, "What we gain from presupposing genes for genocide is unclear. All this serves to do is to absolve the guilty of responsibil- ity, because 'It wasn't our fault, it was just human nature,' which is certainly a perverse use of genetics." Does he think that if such genes did exist, that this would change the moral status of genocide? Hume identified the error, G.E. Moore and many others have explicated it, but somehow the naturalistic fallacy persists. The difficulty in eliminating it may reflect deep, even universal and innate aspects of human cognitive tendencies.

It is a pity that this book disparages the exciting recent scientific advances in evolution and human genetics and the real issues they pose. For instance, regarding human phylogeny, he writes, "We are apes, but only in the same way we are fish," at just the time when genetic studies are making us confident about the relatively recent divergence of the ancestors of humans, chimpanzees and bonobos, and the much earlier split from other lineages. Regarding behavioral genetics, he says, "In the world of twin studies the unscrupulous and the credulous symbiotically plumb the depths of contemporary pseudoscience," just as we are now beginning to identify specific genes that account for heritable individual differences and to understand the immense complexity of gene interactions with other genes and varying environments. And, of course, he ridicules the use of genetic data in anthropology, at just the moment when we are finally able to begin to figure out the geographical origins of the Basques, the Brahmins and Native Americans, to say nothing of whether Cheddar Man's descendents still live in Cheddar.

It is also a pity that this book is so hostile towards contemporary science because this distracts attention from an enterprise that is worthy and perhaps even urgent. He is certainly correct that scientists are often oblivious to their biases, that money often drives what is studied and that scientists' classifications and conclusions have profound and often unanticipated social impacts. But his valid and vivid examples will-for most scientists-be lost in the swirl of his attempts to depreciate some of the most interesting scientific advances of our time. 